Published in Local Government Studies 44(2) (2018), 229-254:

\title{
Metropolitan Challenges and Reform Pressures across Europe - the Perspectives of City Mayors
}

Oliver Dlabac ${ }^{\mathrm{a} *}$, Lluís Medir ${ }^{\mathrm{b}}$, Mariona Tomàs ${ }^{\mathrm{b}}$ and Marta Lackowska ${ }^{\mathrm{c}}$

${ }^{a}$ Centre for Democracy Studies Aarau, University of Zurich, Aarau, Switzerland;

${ }^{b}$ Department of Political Science, Constitutional Law and Philosophy of Law, University of Barcelona, Barcelona, Spain; 'Department of Local Development and Policy, Faculty of Geography and Regional Science, University of Warsaw, Warsaw, Poland

*Correspondence Address: Oliver Dlabac, Centre for Democracy Studies Aarau, University of Zurich, Küttigerstrasse 21, 5000 Aarau, Switzerland. E-mail: oliver.dlabac@zda.uzh.ch

Oliver Dlabac leads the research group on Local Democracy at the Centre for Democracy Studies Aarau and teaches on decentralisation at the University of Zurich. He has published on local and regional democracy in Switzerland and is currently leading a research project on the democratic foundations of urban planning in the city regions of Birmingham, Lyon and Zurich.

Lluís Medir lectures in the Department of Political Science at the University of Barcelona, Spain. His research interests include local government and public policy, and his most recent publication is 'Dealing with Austerity: a case of local resilience in Southern Europe' in Local Government Studies, 2017. He researches in the GREL (www.ub.edu/grel).

Mariona Tomàs is associate professor of Political Science and member of the GREL at the University of Barcelona. Her research focuses on metropolitan governance and urban policies, publishing several articles, book chapters, and comparative studies in the field. She received the Academic Gold Medal of the General Governor of Canada for her PhD in Urban Studies and she won the first prize of the political book of the Parliament of Quebec.

Marta Lackowska is associate professor at the Department of Local Development and Policy, Faculty of Geography and Regional Science, University of Warsaw. Her research is focused on inter-municipal cooperation (she is currently leading a research project comparing IMC in 
European countries), metropolitan governance, urban studies, and local policies. She is a Board member of the European Urban Research Association.

\section{Acknowledgements}

The authors are grateful for the comments made to previous versions of this work by the participants in the 2017 Swiss Political Science Congress in St. Gallen. We also acknowledge the comments made by Michael A. Strebel, Daniel Kübler, Joan-Josep Vallbé, Hubert Heinelt, as well as the anonymous reviewers. 


\title{
Metropolitan Challenges and Reform Pressures across Europe - the Perspectives of City Mayors
}

\author{
Metropolitan governance arrangements and their policy purposes have been a \\ matter of debate among researchers and practitioners around the globe. While we \\ may trace three broad schools of metropolitan governance - reform school, \\ public choice theory and new regionalism - with each still having its proponents, \\ we are interested to learn whether there are assumptions on metropolitan \\ governance that have today become general knowledge among urban political \\ elites. By investigating the attitudes and perceptions of city mayors across \\ Europe, we show that functional multi-purpose governance bodies are indeed \\ more generally associated with equitable service distribution, whereas the \\ preconditions for cost-efficiency and sustainable development are more \\ equivocally placed at different modes of governance. Moreover, we show that a \\ perceived general lack of problem solving capacities does not automatically \\ translate into pressures for metropolitan reform, but it is only in combination with \\ a general disaffection with the governance structures currently in place.
}

Keywords: mayors; metropolitan governance; equity; cost-efficiency, sustainable development; reform pressure

\section{Introduction}

Despite the immense growth of urban areas is Europe (nearly three-quarters of the European population, Eurostat 2014), most of the times the growth of metropolitan areas has not been accompanied by a rational and planned process of metropolitan institution building. In many countries, metropolitan areas have not been institutionally empowered in line with their demographic and economic potential due to political constraints and power struggles.

From a political and institutional perspective, most of the controversy revolves around the reasons and arguments for creating arrangements for collective action, such as a metropolitan government, multi-purpose bodies, inter-municipal contracts, or 
delegation to higher state levels. Indeed, since these concerns are strongly related to the political necessity of solving new (and old) problems at a reasonable (or affordable) cost, the issue of the effectiveness of such institutional architectures naturally emerges. Scilicet, together with more principled preferences for building (or not) metropolitan governments, basic concerns regard the effectiveness of these reforms for tackling local challenges.

Up to present, scarce evidence exists regarding the local elite's preferences for creating metropolitan governments linked to the elite's evaluations of locally existing governance structures and present-day problem-solving capacities at the metropolitan scale. With the financial crisis of 2007, we would argue, issues like metropolitan-wide equity, efficiency and sustainability have further increased in salience. This timely paper aims at filling the research gap by asking whether there is an identifiable pattern across European mayors when it comes to their evaluation of metropolitan governance arrangements and their support for metropolitan reforms. From the current theoretical literature in this field, one might derive various expectations on how mayors evaluate locally existing modes of metropolitan governance in terms of their problem solving capacities. This, in turn, is expected to influence mayors' attitudes towards metropolitan institutionalization.

The present contribution provides valuable insights by linking individual mayors' assessment of metropolitan problem solving capacities and various modes of governance to their preferences for metropolitan institution building. Using the rich data of a recent European-wide survey of city mayors, the article tests, in a first step, the mayoral associations between locally existing modes of governance and their effectiveness in tackling central metropolitan challenges. In a second step, the paper connects the evaluation of such particular modes of governance to the desirability for 
implementing stronger metropolitan institutions. To the best of our knowledge, this work is the first comprehensive study of a set of European mayors accounting for these challenges and pressures for metropolitan reform.

\section{Schools of metropolitan governance meet real-world practitioners}

The debate on how metropolitan areas should be governed has become recurrent not only in the research fields of urban politics and urban studies but also on the political agenda (for a review see Brenner 2002; Heinelt and Kübler 2005; Savitch and Vogel 2009). In academia, there is a consensus on highlighting the existence of three main approaches to metropolitan governance (the reform school, the public choice school and the new regionalism). These three perspectives differ by the way they define main metropolitan problems, the goals to be achieved, the degree of institutionalization of metropolitan cooperation, and the representation of the metropolitan area.

The first approach in the metropolitan debate, the metropolitan reform tradition, considered politico-administrative fragmentation of the region as a problem for solving social inequalities, ensuring an efficient delivery of services and enhancing local democracy. Consequently, its proponents opted for creating a single political unit based on one integrated government for the entire metropolitan area (Stephens and Wikstrom 2000). The first wave of this approach (1930s-1950s) focused on managing intense urban growth outside the core city (Brenner 2002, 7). The second wave came as a response to the opposing public choice school raising in the late 1950s, and focused more on the 'internal sociospatial differentiation and re-differentiation of metropolitan regions’ (Brenner 2002, 7). Its development resulted in relatively numerous undertakings in Europe and the U.S., mainly between 1950 and 1970 (see e.g., Keating 
1995). New reforms in the 1990s and 2000 in Canada and recent reforms in Denmark (2007) illustrate the influence of the reformist approach.

In the late 1950s, the famous article of Tiebout (1956) set the basis for the development of the public choice approach in metropolitan debate. Its proponents support fragmentation of metropolitan areas for the main reasons of protection of local communities, closeness to the citizens, and competition among the independent municipalities (Bish and Ostrom 1973; Tiebout 1956). All the drawbacks of institutional fragmentation can be overcome by the means of voluntary inter-municipal cooperation (creation of single-purpose agencies). This approach has been criticised for its localism and lack of consideration of social inequalities at the metropolitan scale, focussing instead on cost and organisational efficiency in the fragmented region. The abolition of metropolitan governments in the 1980s, like in London (1986) and Barcelona (1987), were inspired by this perspective, as well as the proliferation of special districts in the US as the tool to solve metropolitan problems (Stephens and Wikstrom 2000).

Both traditional approaches were widely criticised, not only from a theoretical perspective, but also due to the very few success examples of their implementation (Lefèvre 1998; Norris 2001). Several factors hampering successful implementation of those approaches were enumerated, including:

(1) for metropolitan reform: fears of meso and local level about losing their powers or even being abolished; unwillingness of central government to empower metropolitan areas by giving them special legal status; reluctance of central government to engage in a difficult political problem (it's hard to satisfy everybody with the details of the reform) which therefore never moves to the top of the political agenda (Lackowska and Norris 2017). These problems show the importance of intergovernmental relations for metropolitan reform. 
(2) for inter-municipal cooperation: organisational, political (losses of power) and financial costs of launching cooperation hamper its development as voluntary process; in most cases (as in the French case) IMC has to be supported by a set of incentives meaning top-down intervention, questioning its bottom-up character. The most quoted and most universal conditions for reaching metropolitan governance were mentioned by Heinelt and Kübler (2005) and include: political will and tradition to cooperate, leadership and incentives. Although the authors assigned them to the new regionalism, they are also true for the public choice perspective.

As a consequence of both global changes and disappointment with the two metropolitan schools, in the 1990s, 'new regionalism' appeared as an alternative conception of metropolitan governance (Savitch and Vogel 2000). The new approach is strongly shaped by the context of globalization and the internationalization of the economy, which has forced metropolitan regions to compete against each other on the global scene (Goldsmith 2005; Denters and Rose 2005). New regionalism has shifted the main attention of the metropolitan debate from its institutional setting to other issues like international competitiveness, inclusion of non-governmental actors and metropolitan citizenship. All these challenges require a coherent metropolitan policy (Brenner 2002; Stephens and Wikstrom 2000) - metropolitan-wide strategies of development have started to flourish since the 2000s (Matusiak 2011). One of the new aspects is sustainable development, especially important for large urban agglomerations willing to keep their attractiveness for new citizens.

The details of the composition of metropolitan arrangement have become less important, even though new regionalists are most willing to see flexible arrangements like strategic planning and multi-purpose arrangements that include a plurality of actors 
as the best way for promoting economic competitiveness, but also for dealing with social inequalities and urban sprawl (Frisken and Norris 2001). Yet, again, new regionalists have been criticised of having difficulties in putting their ideas into practice (Norris 2001; Swanstrom 2001), mainly because the economic competitiveness of a city region has failed to serve as a sufficient incentive for metropolitan cooperation (van der Heiden et al. 2013). However, we can see the influence of neo-regionalist ideas through the creation of public-private initiatives like metropolitan associations for strategic planning (like in Turin or Barcelona) and platforms for economic development (like in Frankfurt, London or Toronto).

As many studies have shown, these theories of metropolitan governance promoted by national and international actors such as governmental agencies, think tanks, international organizations (EU; OECD), city networks (UCLG, Eurocities) have influenced discourses on metropolitan governance on the ground, including political leaders and civil servants, business organisations, social movements and community groups, experts, trade unions, etc. (for some examples, see Keil 2000; Oliver 2000; Feiock and Carr 2001; Boudreau 2003). In many of the studies, a strong focus is placed on citizens' support for metropolitan reform, regardless of the institutional arrangement put in place (e.g., Schaap 2005; Hamilton 2000). Other studies have focused on the citizens' perceptions of metropolitan governance, not only on their perception of metropolitan areas as political and communitarian spaces but also on the specific institutional models of metropolitan governance (mergers, direct election of metropolitan mayors and assemblies; see for instance Kübler 2005; Lidström 2006, 2010, 2013; Lackowska and Mikuła 2015; and Vallbé, Magre and Tomàs 2015).

But also the support of local politicians is taken up as an important reform factor. In relation to the role of mayors, several case studies have analysed their 
preferences and actions for a type of metropolitan arrangement, both from quantitative and qualitative approaches (see for example Baraize and Négrier 2001; Hogen-Esch 2001; Savitch and Vogel 2004; Heinelt and Zimmermann 2011; Mikuła 2011; Tomàs 2012a, 2012b; Dąbrowska and Szmigiel-Rawska 2015).

These studies show that mayors are more inclined to one or another mode of metropolitan governance, this depending mainly on local contextual factors, but also political orientations and preferences of other actors. For instance, the size and shape of the agglomeration (monocentric, polycentric, having a big or small central city), the ideology of the mayor (left-wing, right-wing) and the socio-economic composition of the metropolitan area (high or low inequalities, high or low segregation, poor or rich financial situation) are variables that shape mayors preferences to a specific model of metropolitan governance. Moreover, institutional factors like the political recognition of local governments and their place in the multilevel system of governance (more or less decentralised systems) have been taken into account. Especially important are intergovernmental relations - as we mentioned, various tiers may fear metropolitan arrangements would take away their powers, and in the 'new local democracies' of Central-Eastern and South-Eastern Europe, municipalities which regained autonomy only recently may not be willing to undertake any inter-municipal initiatives (Lackowska 2009). In general, trust and political will to cooperate seem to increase chances for undertaking any kind of metropolitan initiatives.

However, there has been no previous systematic European work on the perceptions of political elites regarding these issues, nor do we know how their evaluations and preferences actually reflect the various schools of metropolitan governance. 


\section{Hypotheses: contextual evaluations, core beliefs, and reform pressures}

For this paper, we propose a basic framework to analyse mayors’ perceptions and attitudes with regard to metropolitan governance and metropolitan reforms. Taking into account the limitations emanating from an evident multicausal environment, we proceed to test our research question related to how to understand individual mayors’ assessments of metropolitan problem solving capacities, together with their support for the creation of metropolitan governments. The specific problem solving capacities investigated here focus on three aspects that are central to the three approaches to metropolitan governance: equitable distribution, cost-efficiency and sustainable development. ${ }^{1}$ As has been highlighted by the existing literature, mayoral satisfaction with problem solving capacity and pressures for metropolitan reforms will depend on a wide range of aspects, including their experience with various elements of their particular metropolitan arrangement (e.g., multi-purpose government, single-purpose units, voluntary cooperation). Additionally we consider mayors’ evaluations as a function of their individual attitudes, their social background as well as their local context, as depicted in figure 1.

[Figure 1 near here]

\footnotetext{
${ }^{1}$ The POLLEADER II survey does not allow for testing propositions regarding the central role of inter-regional competition for creating flexible arrangements mainly aiming at economic promotion of the region for the global market, as suggested by some critical accounts of new regionalism (Brenner 2002). Nonetheless, with sustainable development and cost-efficient service delivery, we cover two aspects that presumably have also been at the heart of new regionalist endeavours, whether for economic or for political motives.
} 
Considering the high number of issues involved and the intricacy of the theorized relationships, several aspects are present that cannot be straightforwardly analysed pooled in a single statistical model. Therefore, the paper depicts the discussed theoretical tensions in two sets of distinct hypotheses. The first group aims at analysing mayoral associations between their local experience with single governance modes and their overall evaluation of metropolitan problem solving capacities, thereby taking into account their individual characteristics and local context. The second hypothesis puts in relation both unsolved challenges in metropolitan governance and core beliefs of mayors to understand the determinants for the support (or not) for creating metropolitan governments.

Generally stated, hypothesis 1 considers that the problem solving capacities reported by a mayor relate to the particular mix of governance modes he or she perceives as currently effective. Rather than investigating the possible causal effects between the actual governance arrangements and their effectiveness as defined by some general criteria, we are thus interested in the subjective associations in the mayors' minds: how do evaluations of single governance modes in place relate to their overall evaluation with regard to equity - or, with regard to cost-efficiency or sustainability? Given the three different challenges under investigation, we formulate three separate sub-hypotheses on associations regarding each.

Since equity is the distinctive focus most clearly tied to reform theory, where metropolitan governance should be multipurpose and hierarchic in order to overcome negative externalities involved in inter-municipal competition and for achieving areawide redistribution, we formulate H1a as follows: 'Mayors satisfied with the degree of equity across the metropolitan area are likely to assign upper-level governments and multi-purpose bodies a stronger present relevance when it comes to the development of 
their metropolitan area, compared to mayors who are discontent with the degree of equity.' This assumption is also in line with the later work on 'City Limits' by Peterson (1981), where we should expect more redistributive policies through allocating competences at higher levels of the political structure. Assuming that the financial crisis of 2007 has accentuated disparities with regard to municipal finances throughout metropolitan areas, we would additionally expect mayors reporting financial hardship to be more strongly disaffected with equitable distribution.

A second sub-hypothesis, H1b, accounts for the main focus of the public choice perspective, which plants inter-municipal cooperation (mainly in the form of intermunicipal contracts and single-purpose organisations) to be the best way for municipalities to ensure cost-efficient production of public services. Therefore, H1b is stated as follows: 'Mayors satisfied with cost-efficiency are likely to attribute a stronger role to inter-municipal cooperation and single-purpose authorities, compared to mayors who are not satisfied with cost-efficiency.' The role of single-purpose authorities, in particular, would further correspond to the new regionalist approach, as it relies on flexible arrangements and public-private partnerships for shaping a competitive economic region in terms of infrastructure and services.

The final sub-hypothesis, H1c, departs from the fact that sustainability is a relatively new issue, recently incorporated into the metropolitan debate. Moreover, the issue per se requires coordinated management of the entire metropolitan area and across different policy fields and can therefore not be achieved under a fragmented management (cooperation between single municipalities). Therefore, 'mayors satisfied with sustainable development report a stronger role of new regionalist approaches, combining multi-purpose governance bodies with (public-private) single-purpose authorities.' In addition to this proposition, we also expect mayors satisfied with 
sustainable development to report a stronger role of upper tiers regulations, as studies on local climate policies show a strong influence of central incentives and policies for locally undertaken actions (Hanssen et al. 2017).

The second main hypothesis is concerned about pressures for reform resulting from the mayoral evaluations of their present governance arrangement and their combined problem solving capacities. More specifically, it is directed towards the most contentious of all metropolitan governance reforms: the creation of a metropolitan government, as proposed by the reform school.

Under this framework, $\mathbf{H} 2$ functions in this way: 'the support for creating metropolitan governments is stronger with mayors sharing core beliefs with the reform school and with mayors perceiving their existing governance-mix as dysfunctional and ineffective with regard to addressing major metropolitan challenges.'

Besides these mayoral evaluations of their governance arrangements and related problem solving capacities, we thus ascribe an important role to previous core beliefs leaning towards a particular school of metropolitan governance. Even though mayors must not actually be familiar with the academic debate between various schools of metropolitan governance, they will nonetheless dispose of some convictions regarding the desirability of amalgamations (reform school) as opposed to inter-municipal cooperation (public choice school). Additionally, we expect leftist mayors, mayors concerned with their municipal finances, and mayors with favourable attitudes towards intergovernmental cooperation to be more supportive of metropolitan reforms.

\section{Data and method}

The analysis draws on data from the POLLEADER II survey (see Heinelt et al. forthcoming), conducted in 28 European countries (plus Israel) between the years 2015- 
2016. The questionnaire was addressed to all mayors of cities with more than $10^{\prime} 000$ inhabitants and the average national response rate was 39 percent, yielding 2691 observations. The wording of survey items used for the following analysis can be found together with the descriptions of transformations in the appendix (table 4).

Even though the items on governance modes and problem solving capacities were only asked to mayors declaring that their city formed part of a larger urban agglomeration (with its meaning explained in the filter question), we filtered the available answers after a cross-validation with the Eurostat (2011) database on larger urban agglomerations ('functional urban areas'). Since the sample included small and more rural countries or countries with many missing values on the metropolitan governance items ${ }^{2}$, we further restricted our database to eight countries counting more than 25 observations, further reducing the data set from 791 to 622 cases. Since the sample universe now consists of all cities above 10’000 located in larger urban agglomerations, the average national response rate now corresponds to 30.3 percent. $^{3}$

${ }^{2}$ The small or more rural countries include Iceland, Cyprus, Latvia, Slovenia, Lithuania, Croatia, Ireland, Slovakia, and Austria; Romania had a very low response rate; many false negatives on the filter question where identified for Albania, Serbia, and Belgium; there were many nonrespondents in the case of England, Norway and Czech Republic; the items were missing altogether in Denmark and Netherlands; a low absolute number of answers further resulted for Hungary and Portugal.

${ }^{3}$ The response rate does not account for Greece since we lack information on the national sample universe, given the wide-ranging territorial reforms since the Eurostat classification of 2011. 
The following section gives an overview of the variables of interest for the selected countries.

Important data transformations refer to the battery on the effectiveness of single governance modes in place in a given metropolitan area. High values on the single items suggest that the respective governance mode is a relevant component of the local governance-mix, having an actual impact on the development of the metropolitan area. In order to discriminate the relative relevance of particular modes also for mayors perceiving most of the governance modes as effective, we created dummy variables indicating that the governance mode was not only perceived as (rather) effective, but also more effective than the median response in that battery.

Additionally, in view of the analysis on the pressures for metropolitan reform, we developed a dichotomous variable regarding the correspondence of mayoral core beliefs with the basic assumptions of either the reform school or the public choice school. Mayors were asked whether they conceived inter-municipal cooperation or amalgamation as more effective with regard to four criteria: professionalization, service quality, cost saving, and political participation. If mayors ticked amalgamation more often than inter-municipal cooperation, we considered their core beliefs as being in line with the reform school as opposed to the public choice school. ${ }^{4}$

\footnotetext{
${ }^{4}$ Since the new regionalist approach is more flexible in terms of the institutionalisation of governance arrangements, our proxy for core beliefs refers to the old metropolitan debate, demarcating reformist assumptions from public choice theory. These are useful reference points, since the second part of our paper is concerned exactly with the question of metropolitan institutionalisation.
} 
As for the method, we use ordered logistic hierarchical (multi-level) regressions, nesting mayors and their cities (level 1) in their metropolitan area (level 2) and their country. Since the number of countries does not allow to adequately specifying models for explaining cross-country variation, we use fixed country effects in order to control for the particularities of each country (e.g., institutional setting, ongoing or completed national reforms, the national political discourse, socio-economic context).

\section{Mayoral evaluations and reform pressures across Europe}

Before we turn to the actual regressions, we here present the overview of the key variables of interest for our subsample of eight countries (table 1). Based on the evaluations of mayors, we realise that most modes of governance do have at least some relevance in most countries. It is clear that metropolitan governance often involves multiple modes of governance at once. Top down regulations and transfers combined with inter-municipal cooperation, sometimes taking the form of single-purpose authorities or multi-purpose governance bodies. Often, upper-level governments themselves provide the legal basis and incentives for inter-municipal cooperation and creating supra-local authorities (see, e.g., Heinz 2000). Where multi-purpose governance bodies exist, they are usually charged with deciding on strategic directions and coordinating various sectoral policies, whereas the implementation of sectoral policies might be delegated to single-purpose authorities (e.g., in Germany or Central Eastern Europe).

Looking at national patterns in the table, we can see that the present relevance of upper-level support for addressing metropolitan challenges is perceived as rather limited in almost all countries except in Greece and Spain or federal Switzerland, where the cantons assume some tasks related to metropolitan governance. However, even these 
countries follow the general pattern evident from the table: the dominating role attributed to inter-municipal contracts and cooperation. That governance mode is often complemented through single-purpose authorities (Poland and the federal countries Germany and Switzerland) and/or through multi-purpose governance bodies (France, Germany, Sweden, Poland). Yet only in France is the ubiquitous dominance of intermunicipal cooperation surpassed by multi-purpose governance bodies effectively steering metropolitan developments. Mayors in Italy, in contrast, seem to be solely trusting inter-municipal solutions, with other modes of governance perceived as either irrelevant or ineffective. Given the strong dominance of inter-municipal cooperation across virtually all countries, it is difficult to find cross-national patterns linking specific governance modes with problem solving capacities in one of the three fields (see respective columns in table 1) - the 'specific governance mode' for most countries is inter-municipal cooperation.

Finally, support for establishing a metropolitan government is evident only in Italy, with Greece and Spain seeming slightly positive about this idea. Even though mayors in these countries are generally satisfied with metropolitan problem solving capacities, they are also the most critical in terms of present-day multi-purpose governance bodies. In Italy, the finding suggests a clear support for the nation-wide metropolitan reform (Crivello and Staricco 2017), implemented only shortly after the survey. In contrast, mayors in France, Germany and Sweden, reporting reasonable effectiveness of their existing multi-purpose arrangements, are amongst the fiercest opponents of metropolitan reforms, with the strongest 'no' coming from Sweden.

[Table 1 near here]

[Figure 2 near here] 
Beyond the discussed cross-national patterns, it would be interesting to relate mayoral evaluations to the actual governance structures in their respective metropolitan areas. While corresponding data would be difficult to gather regarding single purpose authorities or inter-municipal cooperation, with regard to multi-purpose governance bodies we can adhere to the OECD Metropolitan Governance Survey (Ahrend, Gamper and Schumann 2014), published around the time we conducted the mayoral survey. We complemented their coding for all cities figuring in the regressions below. Figure 2 shows that even in areas with full-fledged metropolitan governments, mayors do not generally perceive this body as particularly effective for addressing metropolitan challenges. Still, there are clearly more satisfied mayors in these areas compared to areas with only soft governance bodies or without metropolitan governance bodies altogether.

\section{Mayoral associations between governance modes and problem-solving capacities}

Our analysis brings evidence for hypothesis 1 , stating that specific problem solving capacities are associated with the particular mix of governance modes perceived as currently effective. We tested this hypothesis by a regression model for each of the three challenges under investigation (table 2).

Regarding equitable distribution, a favourable evaluation seems to coincide with multi-purpose governance bodies being perceived as effective (model M1). We must note however, that this association is purely subjective, since we do not find any significant effect for the existence of either a metropolitan governance body or a metropolitan government. Rather than concluding a unidirectional causal relation from actual governance structures to actual problem solving capacities, we simply note that mayors who are satisfied with equitable distribution of public services across their 
region tend to emphasise the role of their multi-purpose metropolitan governance arrangements above the role of other governance modes. Inversely, mayors evaluating their multi-purpose governance bodies are likely to use equity as an evaluation criterion. An additional regression model (appendix, table 5) suggests that this finding holds for the entire population of mayors, and not just for mayors sharing core beliefs with the metropolitan reform school. ${ }^{5}$

Positive evaluations of cost-efficiency, in contrast, seem to be less unanimously linked to multi-purpose governance bodies, since effective inter-municipal cooperation equally seems to have a positive effect (model M2). Besides, there is some evidence for a positive association with support and regulations from higher state levels. We here focus on the stronger two effects and check whether multi-purpose governance bodies and inter-municipal cooperation achieve the effect in combination or separately. We calculate an additional model (M3) including an interaction term with both governance modes. Since the interaction term is insignificant, there seems to be a substantial share of mayors associating efficiency with multi-purpose bodies in some instances and another substantial share of mayors associating efficiency with inter-municipal cooperation in other instances. Whether cost-efficiency is associated with multi-purpose bodies or with inter-municipal cooperation seems not to depend on the mayors' core beliefs corresponding either to the reform school or to public choice theory (appendix, table 5). As was the case with regard to equity, the association with multi-purpose

${ }^{5}$ Our hypotheses and regression models presume general associations between governance modes and problem solving capacities across the entire population of city mayors. The interaction term added to the respective model in table 5 (appendix) is insignificant, indicating that the found associations are not conditional upon a mayor's core beliefs in line with the metropolitan reform school. 
governance body pertains solely to the question whether a mayor perceives a city's metropolitan governance body as relevant, whereas the mere existence of a governance body or metropolitan government is not essential.

Lastly, the perceived capacities for implementing a sustainable metropolitan development strategy seem to be strongly related to the perception of inter-municipal cooperation as working effectively (M4). Additionally, mayors perceiving a stronger role of upper-level governments tend to be more satisfied with their metropolitan capacities with regard to sustainable development. Once again, we test the combined effect for both governance modes. We find that perceived capacities for sustainable development remain strongly related to a mayor’s assessment of inter-municipal cooperation as effective or not (M5). The combined effect and also the independent effect by upper-level governments, however, do not reach any conventional levels of statistical significance. In either case, mayoral associations again seem to be driven by their local experiences rather than their previous core beliefs being in line with one or the other metropolitan governance school (appendix, table 5).

In general, we note that individual, city or regional characteristics do not have a systematic impact on the mayoral evaluations of problem solving capacities - with few exceptions in the case of sustainability. Here, leftist mayors seem to be generally more satisfied with the efforts for sustainable development in their region, as do mayors in capital city regions, whereas satisfaction is generally lower in the larger cities within the metropolitan regions. Interestingly, the challenge of equal distribution seems not to be perceived more strongly by leftist mayors or by mayors reporting a poor financial situation of their municipality. This is a remarkable finding, suggesting that the strained public finances after the financial crisis of 2007 has not generally led to increased tensions within or across metropolitan areas. Also at the metropolitan level, whether the 
area pertains to a smaller, secondary or capital city region does not seem to make a difference when it comes to perceptions of the achieved equity or efficiency. Different from the case of sustainability, within-country variance at the metropolitan level is almost inexistent in these two domains.

In sum, whereas most of our control variables at individual, city and regional level seem to be of little relevance for mayoral evaluations of metropolitan problem solving capacities, the perception of their particular metropolitan governance structures clearly is related to these evaluations, thus confirming our hypothesis 1 . In line with the metropolitan reform school, mayors seem to associate equitable development with multi-purpose governance bodies (H1a). Against our expectation, however, they do not seem to credit upper-level government support when achieving satisfactory development concerning equity. Our finding regarding cost-efficiency shows that some mayors actually relate satisfactory levels of cost-efficiency with effective intermunicipal cooperation as advocated by public choice theorists (H1b), whereas in other cases they seem to recognise the potential contribution of multi-purpose governance arrangements to cost-efficiency as expected by the metropolitan reform school. City mayors, however, do not systematically relate single-purpose authorities with efficiency gains, as opposed to new regionalist assumptions. Lastly, against our expectations, mayors associate sustainable development mainly with the effectiveness of intermunicipal cooperation, rather than with new regionalist governance structures with single- or multi-purpose authorities (H1c). In fact, since public choice theory was more concerned about efficient service delivery and local self-determination, this finding might also indicate a general recognition that a lack of inter-municipal cooperation hinders the effective implementation of sustainable development policies.

[Table 2 near here] 


\section{Pressures for metropolitan reform}

Our second main hypothesis assumed that pressures for creating a metropolitan government could be explained with individual's perceptions of the general problem pressure, overall dysfunctionality of the governance structure, and their previous core beliefs leaning towards a particular school of metropolitan governance. The regression in table 3 shows that perceptions of problem pressure and dysfunctional governance indeed increase the probability of supporting a metropolitan reform - yet this effect holds only when the two factors appear together. In contrast, if mayors perceive strong problem pressures but attest at least one of the governance modes to work effectively, they will be unlikely to support a metropolitan reform. The same is true for mayors perceiving all governance modes as dysfunctional, but being less concerned about the overall problem pressure. Interestingly, mayors sharing central beliefs with the metropolitan reform school are not generally more likely to endorse a metropolitan reform. We only find evidence for a light conditioning effect of mayoral core beliefs, with reform-attuned mayors reacting less reluctantly when facing extensive metropolitan problem pressures.

From figure 3, we can further appreciate how the three effects interact. In order to simplify interpretation, we treated the dependent variable as continuous and based the conditional effects on a replicated linear two-level regression (see online appendix, table 6). The figure shows how the aforementioned interaction effect is less pronounced with mayors leaning towards the reform school ideology (upper two panels). Mayors that are less fond of amalgamations and rather believe in the superiority of intermunicipal cooperation, however, react in two opposing directions when confronted with metropolitan pressures (lower two panels). If at least one other governance mode is perceived as working effectively, they clearly abstain from a metropolitan reform. 
However, if all governance modes in place are failing, they are clearly more willing to engage in the metropolitan experiment.

Back at the regression table, once more the financial crisis and municipal finances seem to be irrelevant with regard to mayoral assessments regarding the need for metropolitan reform. Mayors perceiving their financial situation as (rather) poor are not more likely to support metropolitan reforms, all other things equal. Instead, our items on inter-governmental relations reveal a weak positive effect of mayors arguably taking a more positive stance towards cooperation, whereas defending the role of local governments in the political system rather seems to undermine the support for creating a metropolitan government. From the individual control variables, we find leftist and elder mayor to be more supportive of metropolitan government reforms.

[Table 3 near here]

[Figure 3 near here]

\section{Conclusions}

To start with, our descriptive analysis allows for a cross-national investigation of the satisfaction with existing governance structures, metropolitan problem solving capacities and the resulting pressures for metropolitan reform - everything from the perspective of city mayors and at a time of heightened fiscal pressures following the financial crisis of 2007. Departing from the three ideal-typical schools of metropolitan governance, we developed two main hypotheses on mayoral considerations when evaluating existing supra-local governance structures and when calling for metropolitan reforms.

Based on our regression analyses, we can confirm that mayors associate particular governance modes to particular problem solving capacities - our hypothesis 1 
- and that the association between multi-purpose governance arrangements and equitable distribution is the one shared most unanimously. With regard to the question of metropolitan reform, the most contentious issue seems to be cost-efficiency, since mayors associate cost-efficiency with the two governance modes pertaining to the opposing schools of metropolitan governance: reform school and public choice theory. Whether they attribute cost-efficiency to multi-purpose governance bodies or intermunicipal cooperation seems to be mainly related to the individual perceptions and experiences with existing governance structures, rather than to principled conformity with the basic assumptions of either one or the other school. This shows that theoretical concepts of the metropolitan debate are in practice overlapping, with various effects being achieved by the means of various governance modes and mixtures.

In view of our second hypothesis on pressures for metropolitan reform, we found no evidence for increased tensions emanating from the financial crisis and its differential impact on municipal finances. In fact, we found only a small group of mayors supporting the establishment of a metropolitan government. In line with our hypothesis, however, this group is best characterised as perceiving strong metropolitan problem pressures and being discontent with locally existing governance modes altogether. One or the other element alone yields the opposite result of shying away from any reform experiments at the metropolitan level. Again, more principled beliefs at the heart of the dispute between various schools of metropolitan governance - seem to have only a subordinated role in the real world debate about metropolitan governance.

While mayors today seem to have internalised some of the concurrent expectations of the various ideal typical metropolitan governance schools, their evaluations of locally existing governance modes and the support for metropolitan 
reform seem to work on more pragmatic grounds, based on experience rather individually held principled beliefs, holding dear to proven structures also, and especially in times of turbulence. 


\section{References}

Ahrend, R., C. Gamper, and A. Schumann. 2014. “The OECD Metropolitan Governance Survey: A Quantitative Description of Governance Structures in Large Urban Agglomerations.” OECD Regional Development Working Papers 2014/04. Paris: OECD Publishing.

Baraize, F., and E. Négrier. 2001. L'Invention Politique de l'Agglomération. Paris: L'Harmattan.

Bish, R. L., and V. Ostrom. 1973. Understanding Urban Government: Metropolitan Reform Reconsidered. Washington, D.C.: American Enterprise Institute for Public Policy Research.

Boudreau, J.-A. 2003 “Questioning the Use of 'Local Democracy' as a Discursive Strategy for Political Mobilization in Los Angeles, Montreal and Toronto.” International Journal of Urban and Regional Research 27: 793-810.

Brenner, N. 2002. "Decoding the newest "Metropolitan Regionalism" in the USA: a critical overview.” Cities 19 (1): 3-21.

Crivello, Silvia, and Luca Staricco. 2017. 'Institutionalizing Metropolitan Cities in Italy. Success and Limits of a Centralistic, Simplifying Approach’. Urban Research \& Practice 10 (2): 228-38.

Dąbrowska, A., and K. Szmigiel-Rawska. 2015. "Postawy liderów lokalnych wobec współpracy w Obszarze Metropolitalnym Warszawy.” MAZOWSZE Studia Regionalne 16: 87-107.

Denters, B., and L. E. Rose, eds. 2005. Comparing Local Governance : Trends and Developments. Basingstoke: Palgrave Macmillan.

Eurostat. 2014. Eurostat Regional Yearbook 2014. Luxembourg: Publications office of the European Union.

Eurostat. 2011. “EU-28 (Census), correspondence table - LAU2 Nuts, 2010“. Brussels: European Commission. http://ec.europa.eu/eurostat/web/nuts/localadministrative-units (accessed May 1, 2017).

Feiock, R. C., and J. B. Carr. 2001 "Incentives, entrepreneurs, and boundary change. A collective action framework.” Urban Affairs Review 36: 382-405.

Frisken, F., and D.F. Norris. 2001. "Regionalism reconsidered.” Journal of Urban Affairs 23: 467-478. 
Goldsmith, M. 2005. “A New Intergovernmentalism?” In Comparing Local Governance: Trends and Developments, edited by Denters, B. and L. Rose. 228-245. New York: Palgrave.

Hanssen, G. S., Lackowska M., and P. Swianiewicz. 2017. "Local leadership in climate change policies”, accepted for publishing in Transylvanian Review of Administrative Sciences

Hamilton, D. K. 2000. “Organizing Government Structure and Governance Functions in Metropolitan Areas in Response to Growth and Change: A Critical Overview.” Journal of Urban Affairs 22 (1): 65-84.

Heiden, Nico van der, Philippe Koch, and Daniel Kübler. 2013. 'Rescaling Metropolitan Governance: Examining Discourses and Conflicts in Two Swiss Metropolitan Areas'. Urban Research \& Practice 6 (1): 40-53.

Heinelt, H., and D. Kübler, eds. 2005. Metropolitan Governance: Capacity, democracy and the dynamics of place. London: Routledge.

Heinelt, H., and K. Zimmermann. 2011. "How Can We Explain Diversity in Metropolitan Governance within a Country?' Some Reflections on Recent Developments in Germany”. International Journal of Urban and Regional Research 35: 1175-1192.

Heinelt, Hubert, Annick Magnier, Marcello Cabria, and Herwig Reynaert, eds. forthcoming. Political Leaders and Changing Local Democracy - The European Mayor. Basingstoke: Palgrave Macmillan.

Heinz, W. 2000. City \& Region - Cooperation or Coordination? An International Comparison, Summary of the institute’s publication. Schriften des Deutschen Instituts für Urbanistik 93.

Hogen-Esch, T. 2001. "Urban Secession and the Politics of Growth. The Case of Los Angeles”. Urban Affairs Review 36: 783-809.

Keating, M. 1995. “Size, Efficiency and Democracy: Consolidation, Fragmentation and Public Choice.” In Theories of Urban Politics, edited by Judge, D., G. Stoker, and H. Wolman. 117-134. London: Sage Publications.

Keil, R. 2000. “Governance Restructuring in Los Angeles and Toronto: Amalgamation or Secession?” International Journal of Urban and Regional Research 24: 758781. 
Kübler, D. 2005. La métropole et le citoyen. Lausanne: Presses polytechniques et universitaires romandes.

Lackowska, M. 2009. Zarzadzanie obszarami metropolitalnymi w Polsce. Między dobrowolnościa a imperatywem. Warszawa: Wyd. Uniwersytetu Warszawskiego.

Lackowska, M., and L. Mikuła. 2015. "How metropolitan can you go? Citizenship in Polish City-Regions.” Journal of Urban Affairs.

Lackowska M., and N. F. Norris. 2017. “Metropolitan governance (or not!) in Poland and the United States”, Miscellanea Geographica 21(3): 114-123.

Lefèvre, C. 1998. "Metropolitan government and governance in Western countries: A critical review”, International Journal of Urban and Regional Research 22 (1): 9-25.

Lidström, A. 2006. "Commuting and citizen participation in Swedish city-regions.” Political Studies 54 (4): 865-888.

Lidström, A. 2010. “Citizens’ Intermunicipal Political Orientations: Evidence from Swedish City-regions.” Urban Studies 47 (10): 2093-2109.

Lidström, A. 2013. “Citizens in the City-regions. Political Orientations Across Municipal Borders.” Urban Affairs Review 49 (2): 282-306.

Matusiak, M., ed. 2011. Strategie rozwoju wybranych obszarów metropolitalnych $w$ Europie. Rekomendacje dla aglomeracji poznańskiej. Poznań: Bogucki Press.

Mikuła, Ł. 2011. Funkcjonowanie i integracja aglomeracji poznańskiej w opinii mieszkańców i polityków lokalnych. Poznań: Bogucki Wydawnictwo Naukowe.

Norris, D. F. 2001. "Prospects for Regional Governance under the New Regionalism: Economic Imperatives versus Political Impediments.” Journal of Urban Affairs 21: 557-572.

Oliver, J. E. 2000. “City Size and Civic Involvement in Metropolitan America.” American Political Science Review 94: 361-373.

Peterson, P. E. 1981. City limits. Chicago: University of Chicago Press.

Savitch, H. V., and R. K. Vogel. 2009. “Regionalism and urban politics.” In Theories of urban politics, edited by J. S. Davies and D. L. Imbroscio, 106-124. 2nd ed. London: Sage.

Savitch, H. V., and R. K. Vogel. 2004. "Suburbs without a City. Power and CityCounty Consolidation.” Urban Affairs Review 39 (6): 759-790. 
Savitch, H. V., and R. K. Vogel. 2000. "Paths to new regionalism.” State and local government review 32: 158-168.

Schaap, L. 2005. "Reform and democracy in the Rotterdam region: an evaluation of the attempt to create a regional government.” In Metropolitan Governance: Capacity, democracy and the dynamics of place, edited by H. Heinelt and D. Kübler, 133-150. London: Routledge.

Stephens, G. R., and N. Wikstrom. 2000. Metropolitan Government and Governance: Theoretical Perspectives, Empirical Analysis, and the Future. New York: Oxford University Press.

Swanstrom, T. 2001. "What we argue about when we argue about regionalism.” Journal of Urban Affairs 23: 479-496.

Tiebout, C. M. 1956. “A Pure Theory of Local Expenditures.” Journal of Political Economy 44: 416-424.

Tomàs, M. 2012a. "Exploring the metropolitan trap: the case of Montreal.” International Journal of Urban and Regional Research 36 (3): 554-67.

Tomàs, M. 2012b. Penser métropolitain? La bataille politique du Grand Montréal. Québec: Presses de l’Université du Québec.

Vallbé, J. J., J. Magre, and M. Tomàs. 2015. “Being metropolitan: the effects of individual and contextual factors on shaping metropolitan identity.” Journal of Urban Affairs. 


\section{Appendix}

[Table 4 near here]

[Table 5 near here]

Online Appendix

[Table 6 near here] 
Table 1: Overview of key variables for selected eight countries, 2015/16

\begin{tabular}{|c|c|c|c|c|c|c|c|c|c|}
\hline & & \multicolumn{4}{|c|}{ Relevance of governance modes in place } & \multicolumn{3}{|c|}{ Problem solving capacities } & \multirow[b]{2}{*}{$\begin{array}{l}\text { Support for reform } \\
\\
\text { Creating } \\
\text { metropolitan } \\
\text { government(s) }\end{array}$} \\
\hline & & $\begin{array}{l}\text { Support and } \\
\text { regulations by } \\
\text { upper-level } \\
\text { governments }\end{array}$ & $\begin{array}{l}\text { Multi-purpose } \\
\text { governance bodies } \\
\text { for the urban } \\
\text { agglomeration }\end{array}$ & $\begin{array}{l}\text { Single-purpose } \\
\text { authorities / special } \\
\text { purpose districts }\end{array}$ & $\begin{array}{l}\text { Inter-municipal } \\
\text { contracts and } \\
\text { cooperation }\end{array}$ & $\begin{array}{l}\text { Implementing an } \\
\text { area-wide } \\
\text { sustainable } \\
\text { development } \\
\text { strategy (limiting } \\
\text { sprawl, protecting } \\
\text { natural resources) }\end{array}$ & $\begin{array}{c}\text { Cost-efficient } \\
\text { production and } \\
\text { delivery of public } \\
\text { goods and services } \\
\text { (e.g. energy, water, } \\
\text { waste, maintenance, } \\
\text { public safety) }\end{array}$ & $\begin{array}{c}\text { Equitable } \\
\text { distribution of } \\
\text { public goods and } \\
\text { services across the } \\
\text { larger urban } \\
\text { agglomeration (e.g. } \\
\text { education, culture, } \\
\text { health, social } \\
\text { welfare, adequate } \\
\text { housing, } \\
\text { transportation, area } \\
\text { development) }\end{array}$ & \\
\hline \multirow[t]{2}{*}{ Greece } & Mean & 3.41 & 3.03 & 3.06 & 3.81 & 4.13 & 3.90 & 3.97 & 3.13 \\
\hline & $(\mathrm{N})$ & (32) & (32) & (32) & (32) & (32) & (30) & (32) & (31) \\
\hline \multirow[t]{2}{*}{ Spain } & Mean & 3.38 & 3.15 & 2.66 & 3.88 & 4.05 & 4.13 & 4.15 & 3.11 \\
\hline & $(\mathrm{N})$ & $(137)$ & (136) & $(134)$ & (137) & (142) & (142) & $(141)$ & $(142)$ \\
\hline \multirow[t]{2}{*}{ Switzerland } & Mean & 3.13 & 3.11 & 3.31 & 3.82 & 3.84 & 3.67 & 3.00 & 2.77 \\
\hline & $(\mathrm{N})$ & (45) & (45) & (45) & (44) & (45) & (45) & (45) & (52) \\
\hline \multirow[t]{2}{*}{ France } & Mean & 2.88 & 3.68 & 2.88 & 3.15 & 3.55 & 3.88 & 3.12 & 2.68 \\
\hline & (N) & (33) & (34) & (33) & (34) & (33) & (33) & (33) & (38) \\
\hline \multirow[t]{2}{*}{ Germany } & Mean & 2.83 & 3.30 & 3.62 & 3.73 & 3.50 & 3.57 & 3.37 & 2.85 \\
\hline & (N) & (192) & (192) & (191) & (192) & (195) & (194) & (193) & \multirow[t]{3}{*}{ (192) } \\
\hline \multirow[t]{2}{*}{ Poland } & Mean & 2.84 & 3.21 & 3.23 & 3.72 & 3.27 & 3.66 & 3.87 & \\
\hline & $(\mathrm{N})$ & (49) & (48) & (47) & (47) & (62) & (61) & (62) & \\
\hline \multirow[t]{2}{*}{ Italy } & Mean & 2.73 & 3.02 & 2.26 & 3.91 & 4.00 & 3.98 & 3.82 & 4.09 \\
\hline & (N) & (45) & (44) & (42) & (45) & (44) & (43) & (44) & (46) \\
\hline \multirow[t]{2}{*}{ Sweden } & Mean & 2.48 & 3.23 & 2.96 & 3.52 & 3.19 & 3.81 & 3.04 & 1.73 \\
\hline & $(\mathrm{N})$ & (27) & (26) & (27) & (27) & (27) & (27) & (27) & (30) \\
\hline
\end{tabular}

Remarks: Countries sorted by support from upper-level governments. Scale for governance modes and problem solving capacities from 1 (not effective at all) -5 (highly effective). Scale for support for reform from 1 (highly undesirable) - 5 (highly desirable). $(\mathrm{N})$ = number of observations. 
Table 2: Ordered logit two-level models for explaining mayoral perceptions of problem solving capacities

\begin{tabular}{|c|c|c|c|c|c|}
\hline & \multirow{2}{*}{$\begin{array}{c}\text { Equity } \\
\text { M1 }\end{array}$} & \multicolumn{2}{|c|}{ Efficiency } & \multicolumn{2}{|c|}{ Sustainability } \\
\hline & & M2 & M3 & M4 & M5 \\
\hline \multicolumn{6}{|l|}{ LEVEL 1: MAYOR / CITY } \\
\hline \multicolumn{6}{|l|}{ Perception of relevant governance modes in place (dummies) } \\
\hline \multirow{2}{*}{ - Upper-level government support and regulation (ULG) } & 0.38 & $0.49^{*}$ & $0.50^{*}$ & $0.54^{*}$ & 0.29 \\
\hline & $(0.24)$ & $(0.24)$ & $(0.24)$ & $(0.24)$ & $(0.30)$ \\
\hline \multirow[t]{2}{*}{ - Multi-purpose governance bodies (MPG) } & $0.72^{* *}$ & $0.92^{* * *}$ & $0.86^{* *}$ & 0.39 & 0.43 \\
\hline & $(0.23)$ & $(0.25)$ & $(0.33)$ & $(0.23)$ & $(0.23)$ \\
\hline \multirow[t]{2}{*}{ - Single-purpose authorities } & 0.14 & 0.17 & 0.19 & -0.35 & -0.33 \\
\hline & $(0.25)$ & $(0.26)$ & $(0.27)$ & $(0.25)$ & $(0.25)$ \\
\hline \multirow[t]{2}{*}{ - Inter-municipal contracts and cooperation (IMC) } & 0.29 & $0.57^{* *}$ & $0.55^{*}$ & $0.77^{* * *}$ & $0.65^{* *}$ \\
\hline & $(0.19)$ & $(0.19)$ & $(0.21)$ & $(0.19)$ & $(0.21)$ \\
\hline \multirow[t]{2}{*}{ MPG x IMC } & & & 0.14 & & \\
\hline & & & $(0.52)$ & & \\
\hline \multirow[t]{2}{*}{ ULG x IMC } & & & & & 0.71 \\
\hline & & & & & $(0.49)$ \\
\hline \multirow[t]{2}{*}{ Leftist self-placement of mayor (dummy) } & 0.25 & 0.02 & 0.02 & $0.69^{* * *}$ & $0.69^{* * *}$ \\
\hline & $(0.20)$ & $(0.20)$ & $(0.20)$ & $(0.20)$ & $(0.20)$ \\
\hline \multirow[t]{2}{*}{ Age (grand-mean centred) } & 0.01 & 0.00 & 0.00 & 0.01 & 0.01 \\
\hline & $(0.01)$ & $(0.01)$ & $(0.01)$ & $(0.01)$ & $(0.01)$ \\
\hline \multirow[t]{2}{*}{ Male } & -0.21 & 0.09 & 0.09 & -0.06 & -0.03 \\
\hline & $(0.25)$ & $(0.26)$ & $(0.26)$ & $(0.26)$ & $(0.26)$ \\
\hline \multicolumn{6}{|l|}{ Education (ref.: elementary school) } \\
\hline \multirow[t]{2}{*}{ - University degree } & -0.18 & -0.09 & -0.09 & 0.84 & 0.82 \\
\hline & $(0.43)$ & $(0.46)$ & $(0.46)$ & $(0.46)$ & $(0.46)$ \\
\hline \multirow[t]{2}{*}{ - Secondary degree } & -0.18 & -0.21 & -0.21 & 0.41 & 0.39 \\
\hline & $(0.48)$ & $(0.50)$ & $(0.50)$ & $(0.50)$ & $(0.50)$ \\
\hline \multirow[t]{2}{*}{ Financial situation of city perceived as (rather) poor } & 0.26 & 0.15 & 0.15 & -0.11 & -0.09 \\
\hline & $(0.21)$ & $(0.21)$ & $(0.21)$ & $(0.21)$ & $(0.21)$ \\
\hline \multirow[t]{2}{*}{ Population size of municipality (log., grand mean centred) } & -0.17 & -0.15 & -0.15 & $-0.38^{*}$ & $-0.39^{*}$ \\
\hline & $(0.16)$ & $(0.16)$ & $(0.16)$ & $(0.16)$ & $(0.16)$ \\
\hline \multirow[t]{2}{*}{ Centre of metropolitan area } & 0.25 & 0.48 & 0.47 & 0.69 & 0.71 \\
\hline & $(0.37)$ & $(0.38)$ & $(0.38)$ & $(0.38)$ & $(0.38)$ \\
\hline \multicolumn{6}{|l|}{ LEVEL 2: METROPOLITAN AREA } \\
\hline \multicolumn{6}{|l|}{ Metropolitan governance structure (ref.: none) } \\
\hline - Metropolitan governance body & 0.28 & -0.22 & -0.22 & -0.11 & -0.11 \\
\hline & $(0.24)$ & $(0.25)$ & $(0.25)$ & $(0.28)$ & $(0.28)$ \\
\hline - Metropolitan government & -0.01 & -0.42 & -0.40 & -0.24 & -0.23 \\
\hline & $(0.31)$ & $(0.31)$ & $(0.32)$ & $(0.32)$ & $(0.32)$ \\
\hline Type of metropolitan area (ref.: smaller metropolitan area) & & & & & \\
\hline - Secondary functional urban area & -0.02 & -0.13 & -0.13 & 0.18 & 0.18 \\
\hline & $(0.23)$ & $(0.24)$ & $(0.24)$ & $(0.25)$ & $(0.25)$ \\
\hline - Capital functional urban area & 0.22 & -0.11 & -0.11 & 0.69 & 0.70 \\
\hline & $(0.32)$ & $(0.33)$ & $(0.33)$ & $(0.36)$ & $(0.36)$ \\
\hline Log Likelihood & -571.37 & -518.04 & -518.00 & -568.53 & -567.48 \\
\hline Num. obs. & 454 & 428 & 428 & 456 & 456 \\
\hline Groups (metropolitan area) & 173 & 167 & 167 & 174 & 174 \\
\hline Variance: metropolitan area (intercept) & 0.00 & 0.00 & 0.00 & 0.10 & 0.11 \\
\hline
\end{tabular}


Table 3: Ordered logit two-level model for explaining mayoral support for creating metropolitan governments

Reform

LEVEL 1: MAYOR / CITY

All governance modes in place perceived as dysfunctional (dummy) $\quad-2.77^{* *}$

(0.98)

-0.79
$(0.19)$

$\begin{array}{ll}\text { Core beliefs: reform school (dummy) } & -0.80\end{array}$

1.29
$(0.39)$

- All dysfunctional x reformist $\quad 2.21$

$(1.77)$

- Problem pressure x reformist $\quad 0.72^{*}$

$(0.34)$

- All dysfunctional x problem pressure x reformist $\quad-1.06$

Importance of mayoral tasks

- Inter-municipal cooperation $\quad 0.70^{*}$

Defending position of local governments in political system $\quad-0.72^{*}$

Leftist self-placement of mayor (dummy) $\quad 0.58^{* *}$

$(0.21)$

Age (grand-mean centred) $\quad 0.02^{*}$

$(0.01)$

$-0.06$

Male

Education (ref.: elementary school)

- University degree

- Secondary degree

Financial situation of city perceived as (rather) poor $\quad 0.06$

Population size of municipality (log., grand mean centred)

Centre of metropolitan area

LEVEL 2: METROPOLITAN AREA

Metropolitan governance structure (ref.: none)

- Metropolitan governance body $\quad-0.03$

Metropolitan government

Type of metropolitan area (ref.: smaller metropolitan area)

- Secondary functional urban area $\quad 0.76^{* *+}$

$(0.27)$

- Capital functional urban area $\quad-0.30$

$(0.36)$

Log Likelihood $\quad-529.38$

Num. obs. 396

Groups (metropolitan area) $\quad 144$

Variance: metropolitan area (intercept) 0.08

${ }^{* * * *} \mathrm{p}<0.001,{ }^{* * *} \mathrm{p}<0.01,{ }^{*} \mathrm{p}<0.05$. Fixed country effects (not reported). 
Table 4: Operationalization, question wording and measurement (POLLEADER II)

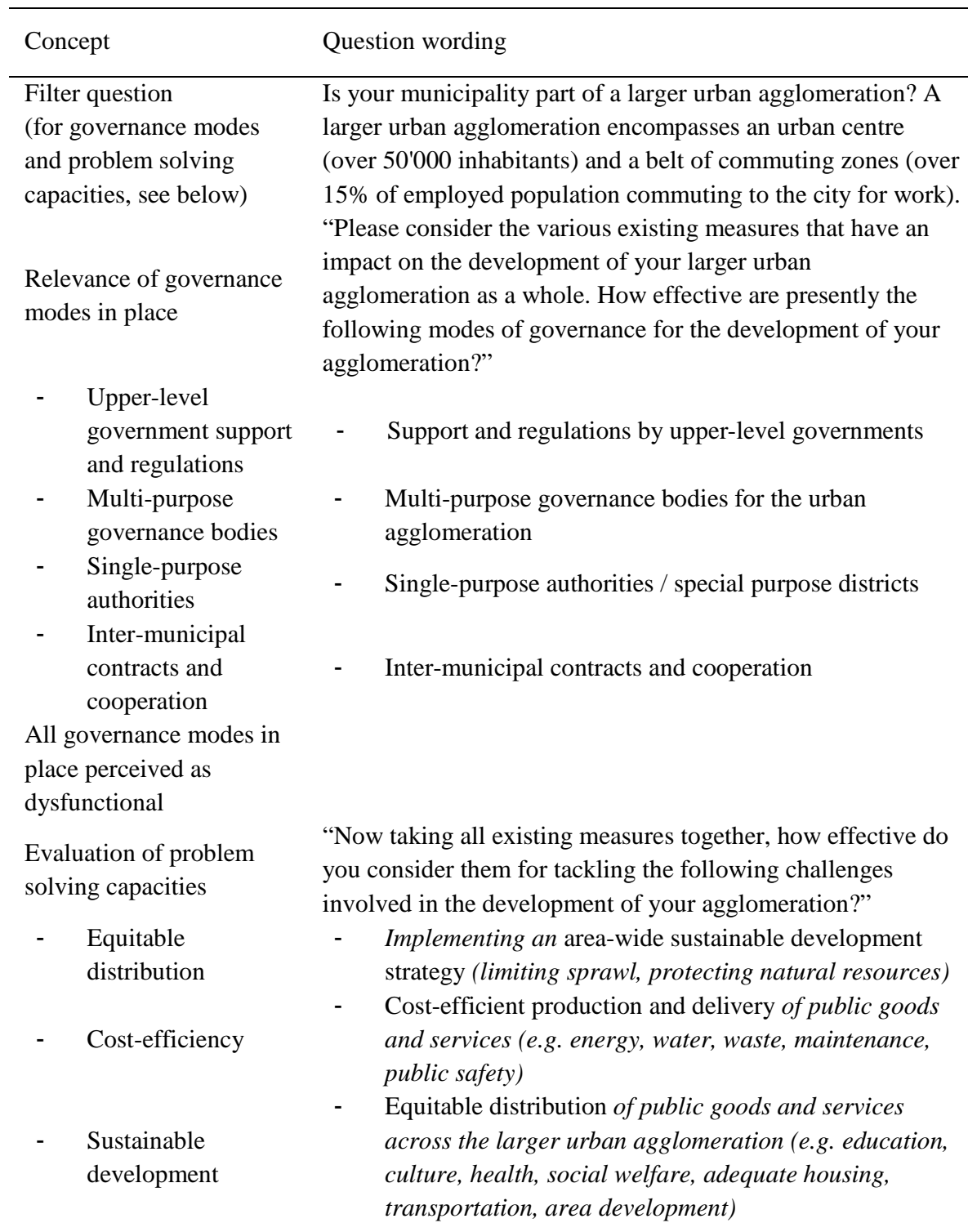

Perceived problem

pressure

Support for creating metropolitan government

Core beliefs: reform

school (vs. public choice)

Importance of mayoral tasks:

"How desirable or undesirable do you consider the following reforms, irrespective of whether they have been introduced in your context?”

- $\quad$ Creating metropolitan government(s)

"Intermunicipal cooperation and amalgamation of municipalities are alternative solutions for rationalizing local government.

Which of them are more effective under the following profiles?” [Third option for each profile: There is no real utility in cooperation or amalgamation]

- $\quad$ Professionalization of administrative staff

- $\quad$ Service quality

- $\quad$ Cost saving

- Political participation

“Many different tasks are associated with the mayor's position.

Original scale and

transformations

$0 / 1$

1 (not effective at all) to

5 (highly effective)

Dummy for each governance mode for its relative relevance: a value above 3 and above the individual median value of all governance modes (allowing for 1 missing)

Dummy for all governance modes with values of 3 and lower.

1 (not effective at all) to 5 (highly effective)

As independent variables: dummy for ineffective problem solving ( $1 / 2$ vs. $3 / 4 / 5)$

Inverse average of all three problem solving capacities together

1 (highly undesirable) to 5 (highly desirable)

Dummy: amalgamation was ticked more often than inter-municipal cooperation

1 (not a task of a mayor) to 5 (of utmost importance) 
- $\quad$ inter-municipal cooperation

- defending position of local governments in political system

Financial situation of city perceived as (rather poor)

Leftist self-placement of mayor
- $\quad$ To foster the co-operation with the neighbouring municipalities

- $\quad$ To defend and promote the influence of local authorities in the political system

Dummy: $4 / 5$ vs. $1 / 2 / 3$

"How would describe the financial situation of your municipality?”

1 (very poor) to 5 (very good)

Dummy: $1 / 2$ vs. $3 / 4 / 5$

"There is often talk about a left-right dimension in politics.

Where would you place yourself on a left-right dimension?"
1 (left) to 10 (right) 
Table 5: Ordered logit two-level model for explaining mayoral perceptions of problem solving capacities, conditional on mayoral reform school ideology

\begin{tabular}{|c|c|c|c|}
\hline & $\begin{array}{c}\text { Equity } \\
\text { M1 }\end{array}$ & $\begin{array}{c}\text { Efficiency } \\
\text { M2 }\end{array}$ & $\begin{array}{c}\text { Sustainability } \\
\text { M4 }\end{array}$ \\
\hline \multicolumn{4}{|l|}{ LEVEL 1: MAYOR / CITY } \\
\hline \multicolumn{4}{|l|}{ Perception of relevant governance modes in place (dummies) } \\
\hline \multirow[t]{2}{*}{ - Upper-level government support and regulation (ULG) } & 0.43 & 0.35 & 0.60 \\
\hline & $(0.25)$ & $(0.26)$ & $(0.31)$ \\
\hline \multirow[t]{2}{*}{ - Multi-purpose governance bodies (MPG) } & $0.77^{* *}$ & $0.85^{*}$ & 0.24 \\
\hline & $(0.29)$ & $(0.35)$ & $(0.24)$ \\
\hline \multirow[t]{2}{*}{ - Single-purpose authorities } & 0.27 & 0.40 & -0.43 \\
\hline & $(0.26)$ & $(0.30)$ & $(0.27)$ \\
\hline \multirow[t]{2}{*}{ - Inter-municipal contracts and cooperation (IMC) } & 0.34 & $0.74^{* *}$ & $1.02^{* * *}$ \\
\hline & $(0.20)$ & $(0.26)$ & $(0.24)$ \\
\hline \multirow[t]{2}{*}{ Core beliefs: reform school (dummy) } & -0.06 & -0.07 & 0.16 \\
\hline & $(0.23)$ & $(0.30)$ & $(0.29)$ \\
\hline \multirow[t]{2}{*}{ - MPG x reformist } & -0.30 & -0.36 & \\
\hline & $(0.51)$ & $(0.62)$ & \\
\hline \multirow[t]{2}{*}{ - IMC x reformist } & & -0.68 & -0.42 \\
\hline & & $(0.45)$ & $(0.44)$ \\
\hline \multirow[t]{2}{*}{ - ULG x reformist } & & & -0.22 \\
\hline & & & $(0.55)$ \\
\hline \multirow[t]{2}{*}{ Leftist self-placement of mayor (dummy) } & 0.23 & 0.05 & $0.75^{* * *}$ \\
\hline & $(0.20)$ & $(0.22)$ & $(0.21)$ \\
\hline \multirow[t]{2}{*}{ Age (grand-mean centred) } & 0.01 & -0.00 & 0.00 \\
\hline & $(0.01)$ & $(0.01)$ & $(0.01)$ \\
\hline \multirow[t]{2}{*}{ Male } & -0.27 & 0.06 & -0.14 \\
\hline & $(0.26)$ & $(0.28)$ & $(0.27)$ \\
\hline \multicolumn{4}{|l|}{ Education (ref.: elementary school) } \\
\hline \multirow[t]{2}{*}{ - University degree } & -0.24 & -0.40 & 0.83 \\
\hline & $(0.44)$ & $(0.48)$ & $(0.47)$ \\
\hline \multirow[t]{2}{*}{ - Secondary degree } & -0.15 & -0.47 & 0.38 \\
\hline & $(0.49)$ & $(0.53)$ & $(0.51)$ \\
\hline \multirow[t]{2}{*}{ Financial situation of city perceived as (rather poor) } & 0.27 & 0.04 & -0.15 \\
\hline & $(0.22)$ & $(0.23)$ & $(0.22)$ \\
\hline \multirow[t]{2}{*}{ Population size of municipality (log., grand mean centred) } & -0.14 & -0.08 & $-0.46^{* *}$ \\
\hline & $(0.17)$ & $(0.20)$ & $(0.18)$ \\
\hline \multirow[t]{2}{*}{ Centre of metropolitan area } & 0.27 & 0.42 & 0.74 \\
\hline & $(0.39)$ & $(0.45)$ & $(0.40)$ \\
\hline \multicolumn{4}{|l|}{ LEVEL 2: METROPOLITAN AREA } \\
\hline \multicolumn{4}{|l|}{ Metropolitan governance structure (ref.: none) } \\
\hline \multirow[t]{2}{*}{ - Metropolitan governance body } & 0.32 & -0.14 & -0.25 \\
\hline & $(0.25)$ & $(0.27)$ & $(0.30)$ \\
\hline - Metropolitan government & 0.14 & -0.11 & -0.25 \\
\hline & $(0.32)$ & $(0.35)$ & $(0.34)$ \\
\hline Type of metropolitan area (ref.: smaller metropolitan area) & & & \\
\hline - Secondary functional urban area & 0.03 & -0.29 & 0.17 \\
\hline & $(0.24)$ & $(0.26)$ & $(0.26)$ \\
\hline - Capital functional urban area & 0.25 & -0.26 & 0.70 \\
\hline & $(0.34)$ & $(0.36)$ & $(0.38)$ \\
\hline Log Likelihood & -513.25 & -425.31 & -502.71 \\
\hline Num. obs. & 408 & 353 & 409 \\
\hline Groups (metropolitan area) & 151 & 125 & 151 \\
\hline Variance: metropolitan area (intercept) & 0.00 & 0.00 & 0.13 \\
\hline
\end{tabular}

${ }^{* * * *} \mathrm{p}<0.001,{ }^{* *} \mathrm{p}<0.01,{ }^{*} \mathrm{p}<0.05$. Fixed country effects (not reported). Models for efficiency without Sweden and France. 
Table 6: Linear two-level model for explaining mayoral support for creating metropolitan governments

\begin{tabular}{ll}
\hline & Reform \\
\hline LEVEL 1: MAYOR / CITY &
\end{tabular}

All governance modes in place perceived as dysfunctional (dummy) $\quad-1.35^{*}$

(0.54)

Perceived problem pressure (inverse of average problem solving capacity) $\quad-0.41^{* * *}$

(0.10)

Core beliefs: reform school (dummy) $\quad-0.28$

$(0.43)$

- All dysfunctional x problem pressure $\quad 0.62^{* *}$

$(0.21)$

- All dysfunctional x reformist 1.07

(0.99)

$\begin{array}{lc}\text { - Problem pressure x reformist } & 0.32\end{array}$

(0.18)

$-0.50$

$(0.35)$

Importance of mayoral tasks

$\begin{array}{lc}\text { - Inter-municipal cooperation } & 0.38^{*}\end{array}$

Leftist self-placement of mayor (dummy) $\quad 0.32^{*}$

$(0.11)$

$0.01^{*}$

$(0.01)$

$-0.01$

Education (ref.: elementary school)

- University degree

$\begin{array}{lr}\text { - Secondary degree } & -0.17\end{array}$

$\begin{array}{ll}\text { Financial situation of city perceived as (rather poor) } & 0.05\end{array}$

$\begin{array}{ll}\text { Population size of municipality (log., grand mean centred) } & 0.16\end{array}$

Centre of metropolitan area $\quad 0.01$

LEVEL 2: METROPOLITAN AREA

Metropolitan governance structure (ref.: none)

- Metropolitan governance body $\quad-0.02$

Metropolitan government

$-0.02$

$(0.21)$

Type of metropolitan area (ref.: smaller metropolitan area)

- Secondary functional urban area $\quad 0.34^{*}$

- Capital functional urban area $\quad-0.14$

\begin{tabular}{lc} 
& $(0.21)$ \\
\hline Log Likelihood & -581.90 \\
Num. obs. & 396 \\
Groups (metropolitan area) & 144 \\
Variance: metropolitan area (intercept) & 0.06 \\
Variance: residual & 0.97 \\
\hline
\end{tabular}

${ }^{* * *} \mathrm{p}<0.001,{ }^{* *} \mathrm{p}<0.01,{ }^{*} \mathrm{p}<0.05$. Fixed country effects (not reported). 
Figure 1: Conceptual framework for the study of perceived problem solving capacities and reform pressures

Mayoral contextual evaluations regarding overall effectiveness

Relevance of various governance

Specific problem solving capacities modes in place

- Upper-level support and regulations

- Multi-purpose bodies

- Single-purpose authorities

- Inter-municipal cooperation

H1

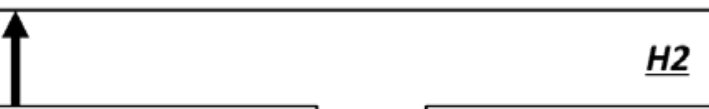

Individual characteristics

- Core beliefs: reform school vs. public choice

- Intergovernmental relations

- Political ideology

- Social background

Local context: perceived financial situation, city type, metropolitan governance structure, type of metropolitan area, country 
Figure 2: Shares of mayors perceiving multi-purpose governance bodies as relevant for addressing challenges in their particular urban agglomeration

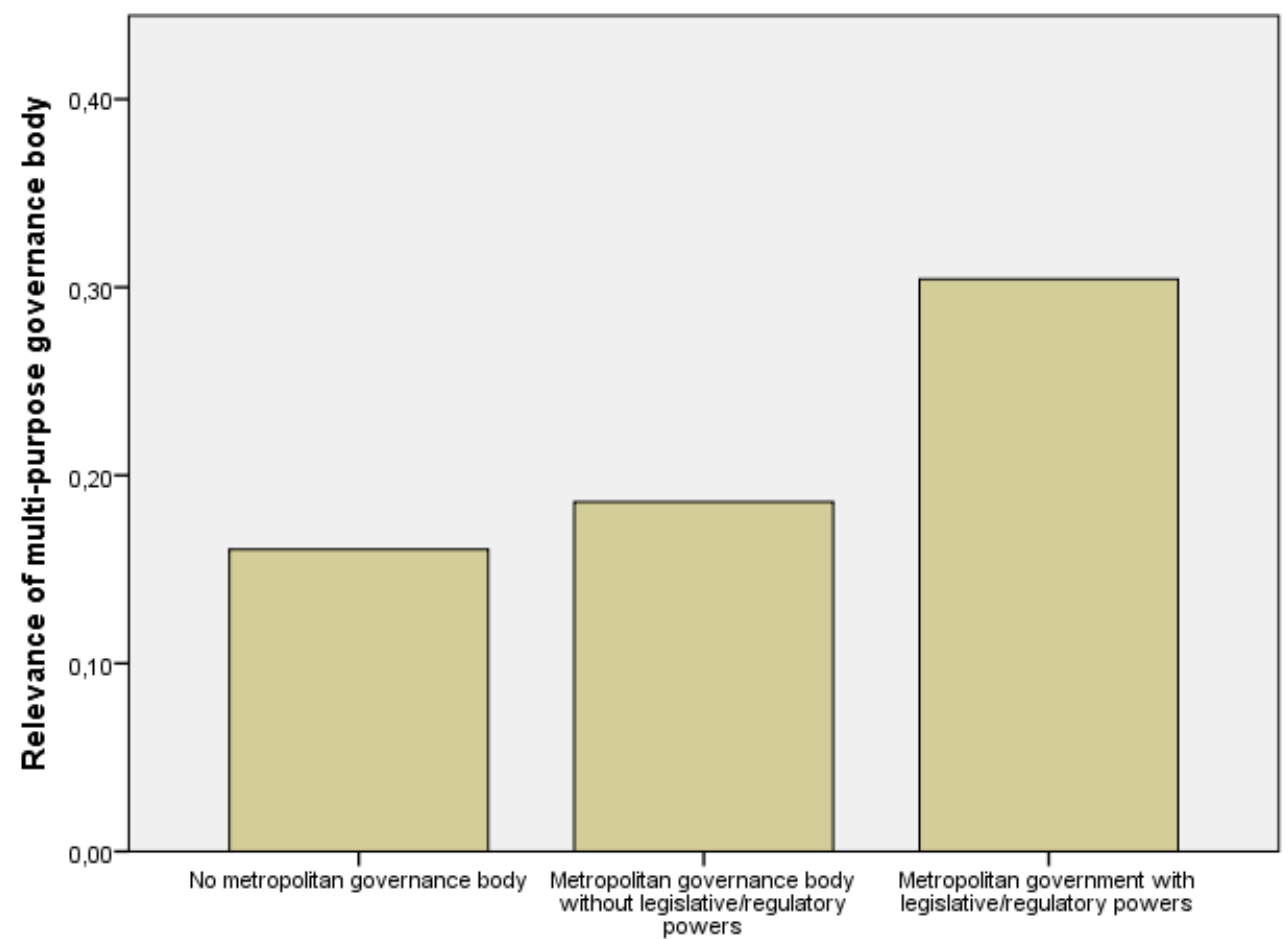

Metropolitan governance structure (cp. OECD Metropolitan Governance Survey, 2014) 
Figure 3: Conditional effects of problem pressures on support for metropolitan reform

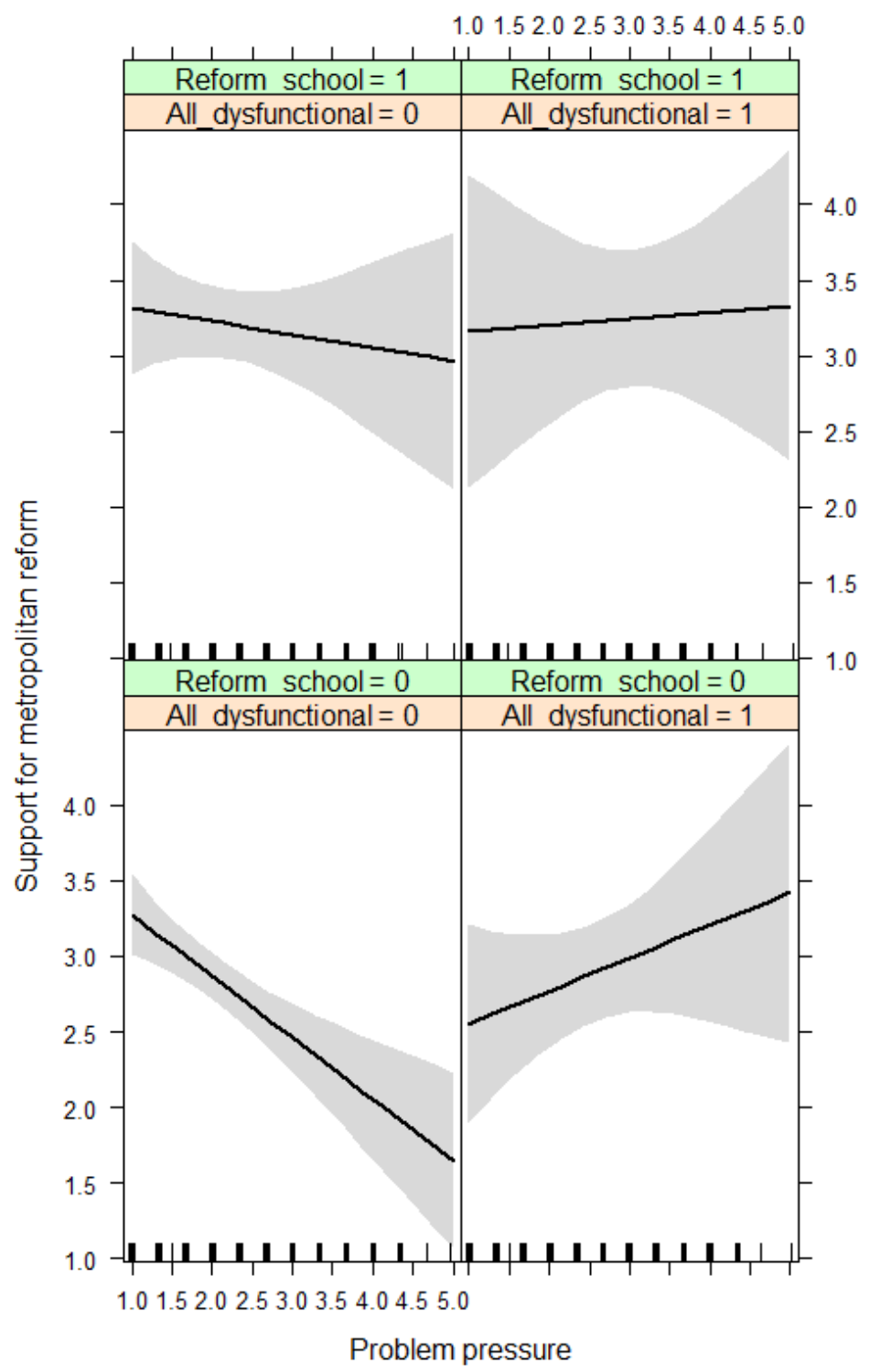

